\title{
A Study of the Vascular System in certain Orders of the Ranales.
}

\author{
BY
}

W. C. WORSDELL, F.L.S.

With Plates XXXII and XXXII, and four Figures in the Text.

I

THE general arrangement of the vascular system in the vegetative organs, viz. the stems and leaves, of a plant is obviously directly correlated with, and the result of, the habit of the plant. Now, according to their habit, plants may be grouped into two main series:-

(I) Grandifoliate plants, in which the stem plays a very subsidiary rôle, the length of its internodes being reduced to a minimum; the leaves, therefore, closely succeed each other, possess wide sheathing bases, and are the dominant organs of the plant, e. g. Palms, Water Lilies.

(2) Parvifoliate plants, in which the stem is the dominant organ of the plant, possessing elongated internodes, and bearing comparatively small leaves with non-sheathing bases, e.g. Elm, Wall-flower.

In the former group, the vascular structure of the stem will be dominated by and similar to that of the leaf, in which the bundles will tend to be scattered throughout the ground-tissue; in the latter group the vascular structure of the stem will be much more independent of, and more unlike, that of the leaf, in which the bundles will tend to be arranged in an arc.

Taking the vegetable kingdom as a whole, $I$ regard the grandifoliate habit as the primitive one, for the simple reason that $I$ consider the bryophytic sporogonium as the prototype and ancestor of all plants; in this structure the vegetatively-modified terminal capsule was the primaeval leaf, dominating, as regards size and general development, the stem (seta) immediately below it. Out of this developed the subsequent leafy plant, by a process of sympodial and lateral branching of phytons ('Stengelglieder'), precisely as occurs in the embryo and seedling of,

Annale of Botany, Vol. XXII. No. LXXXVIU. October, 1908.] 
e. g. Funcus and Pistia at the present day, each branch bearing a terminal leaf, until such period as the stem-apex began precociously to assert itself at each stage and the leaves became displaced from their primitively terminal position into a lateral one. This process is repeated in the embryonic history of the great majority of Monocotyledons and is the explanation of the general and essential grandifoliate habit in this class of plants.

The question has next to be answered whether, for the Angiosperms as a group taken by themselves, the grandifoliate or parvifoliate is the most primitive form of plant. After a full consideration of the facts of morphology, especially those relating to the embryonic history of Angiospermous plants, $I$ arrive at the conclusion that the Monocotyledonous and grandifoliate structure was characteristic of the primitive Angiosperm.

Now, my present object in writing this paper is to show that a comparative study of the vascular tissue of certain orders of Angiosperms strongly supports the position reached as a result of morphological study, viz. that the grandifoliate habit (i. e. a comparatively insignificant stem and large sheathing leaves) in Angiosperms has not been derived by reduction and degeneration from the parvifoliate habit, but is primitive and original. Some would suppose that all geophytes and herbaceous perennials with a subterranean stem have been derived by reduction from tall, subaerial, woody plants, and that many have again acquired the character of these 1atter. But the facts of embryo and seedling morphology, which should, as all botanists teach, reproduce that of the ancestry, do not support this view. In both classes, Dicotyledons and Monocotyledons, the cotyledons are terminal to the axis and the dominating organ of the plant; they are the first organs to appear on the scene, the plumule in the majority of cases arising later and in a lateral position, which, in the case of Dicotyledons, appears terminal, owing to the deep forking of the cotyledon having induced the two resulting lobes to separate widely apart from one another, viz. through an angle of $180^{\circ}$. It may be said that the early development and terminal position of the cotyledons is due to their having become adapted to an absorptive function in the embryo-sac ; but there is no evidence for this ; and further, if the cotyledons are really lateral and subsidiary to the stem, one would expect the latter to become the absorptive organ rather than one of the lateral foliar organs, because of its tendency to appear in advance of the cotyledons. Nor, again, is it at all likely that such highly advanced plants as Dicotyledons should exhibit reduction and degeneration of the embryo ; it might be conceivable in parasites and saprophytes, which are degenerate in some of their mature organs, but not in plants which in no part of their mature organization exhibit degeneration. Again, if the single cotyledon has been derived either by fusion of two cotyledons or the abortion of the second, one would expect that, occasionally, Monoco- 
tyledonous seedlings would exhibit two cotyledons or a bifurcation of the single one; but as far as I am aware none such have ever been found; whereas in Dicotyledonous seedlings cases in which the two cotyledons have fused together into a single organ are very common, and probably, in my opinion, represent reversions to the ancestral condition. And the converse phenomenon of bifurcation of the cotyledons is still commoner, showing that this is the direction in which modification is proceeding, and probably has proceeded in the past in the course of formation of the dicotyledonary character. The above facts and ideas have never been faced by those who hold the opposite view to the one I am here promulgating.

Hence I hold that the presence of two cotyledons in Dicotyledons is merely an illusive appearance. There is only one cotyledon, as in Monocotyledons; this has become so deeply bifurcated in the great majority of
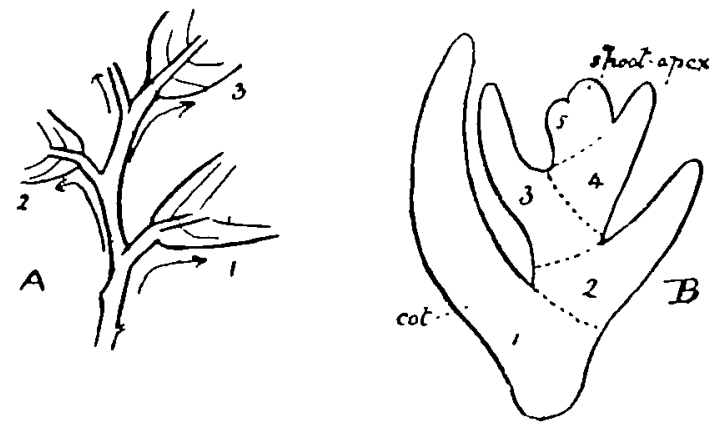

- Trxt-FIg. I.-A. Shoot of Polyalthia, illustrating sympodial structure, i.e. each leaf terminales a stem segment. $B$. Embryo of Monocotyledon, showing similar sympodial structure of plant (after Celakovsky).

cases as to give the appearance of two distinct leaves. In confirmation of this idea I have recently observed a seedling Wallfower in which one of the cotyledons had bifurcated, the two resulting leaves assuming positions with regard to each other precisely like those assumed by the two cotyledons of a normal seedling. Hence the artificial distinction which has always been drawn between the two so-called 'classes' of Angiosperms has not met with much support from the facts of seedling morphology.

I assume, therefore, that every stem or shoot is essentially a sympodium in the sense that each leaf in its turn constitutes the termination of the main axis, the shoot as a whole being continued and built up by means of a succession of branches, each arising (alternately right and left) from the base of the terminal leaf. And this is precisely what actually happens in all Monocotyledonous seedlings at the earliest stage or stages.

I feel more and more inclined to hold the view that Angiosperms have developed dircctly from an ancestor belonging to the Bryophytic level and that they have not come from either Gymnosperms, Pteridosperms, or 
Ferns; on the other hand, it is quite possible that they have descended from a Fern-like ancestor.

In order to determine the nature of the phylogenetic history, we are accustomed to study that of the ontogeny under the right and proper belief that the latter, as a rule, is a condensed recapitulation of the former. But to apply this method right and left, quite regardless of the nature of the prevailing circumstances, as has been done by some botanists, is surely unwise. I am quite unable to follow the argument used by Professor Jeffrey-that because the stem of the seedling Monocotyledon possesses a cylindrical and not a scattered arrangement of the bundles, that therefore the scattered system, as found in the mature stem, has been derived phylogenetically from a cylindrical system. For, supposing, for the sake of argument, that the scattered system of bundles is phylogenetically the primitive one, this character could not possibly be found in the seedling plant, for the cotyledons and earliest foliage-leaves, and, therefore, a fortiori, the stem, are far too rudimentary and limited in spatial tissue-development to be able to exhibit anything of the nature of a ranked or scattered grouping of the vascular bundles; there simply is no room for it; hence the cylindrical arrangement must necessarily and inevitably prevail ; but in proportion as the successively-formed leaves and the stem increase in size does the scattered arrangement gradually begin to appear upon the scene. This is an excellent instance of a case where the ontogenetic history proceeds in a direction the precise reverse of that of the phylogenetic history. It is, therefore, to the adult plant that we must turn in order to unravel the phylogenetic history of the vascular system.

Assuming that the grandifoliate was the primitive condition of the Angiosperm, and that the vascular structure of the stem was derived directly from that of the leaf-and knowing, as we do, that foliar organs tend to retain a primitive structure for a much longer period than is the case with the stem, owing to the greater modification which the latter, as the common carrier of all organs of the plant, must necessarily undergowe should expect that in a good many cases, viz. in those in which the leaves have not as yet followed the stem in the process of modification, a key to the primitive structure of the stem would be found in the present structure of the leaves; and this I believe to be in many instances indeed the case. In these cases, e.g. many Umbelliferae, the stem possesses an almost what I may call typical parvifoliate structure, i. e. with bundles arranged in a ring ; while that of the leaf is typically grandifoliate, i. e. with scattered bundles. Only in rare cases do we find the converse to be true (e. g. Anemume rivularis). In a great many cases both organs are equally and similarly modified.

Now, if we assume, for the sake of argument, the case of a plant undergoing reduction from a parvifoliate to a grandifoliate habit, it is quite 
impossible to imagine the stem remaining parvifoliate in its vascular structure while that of the leaf becomes modified in a grandifoliate direction; in other words, that a condition like that found in many Umbelliferae and other plants could by this method be attained; for no conceivable reason can be adduced for such a change. On the other hand, if the plant is developing out of a grandifoliate into a parvifoliate habit, it is quite conceivable that the stem, for the reasons above given, should become modified in the parvifoliate direction, while the leaf retains its primitive grandifoliate structure. It is also conceivable that the grandifoliate stem, owing to certain structural peculiarities, such as the possession of a thick sclerotic zone, which is adequate to resist bending-strains should, on eventual elongation, retain the grandifoliate structure while the leaf has begun to assume that of the parvifoliate plant. The above inferences strongly favour the truth of my present theory.

In such cases as that of the Umbelliferae the stem-structure is not quite typically parvifoliate, for the primitive ranked or scattered arrangement of the bundles can still be traced there, for although all the bundles may be practically at one level, i.e. in a single ring or series, they are of three or four different sizes, the largest in some, but not all, cases slightly projecting into the pith, while the smallest are outermost and often quite rudimentary. This latter character is due to the fact that in the grandifoliate ancestor all the ranks of bundles would be well-developed and serviceable to the large leaf-base, and therefore to the stem; but on the acquirement by the latter of the cylindric arrangement, owing to the elongation of the internodes and the reduction in comparative size of the leaves, the bundleranks would become condensed and pressed outwards to form a single rank, and the smallest ones, being the most external, would be the first to be obliterated. This can be the only interpretation of the phenomenon; for it is impossible to conceive of the possibility that such plants are modifying their structure in the opposite and converse direction, viz. towards the grandifoliate condition. This is supported by the following facts: In the Ranunculaceae, plants with a primitive floral structure, the grandifoliate habit and vascular structure is pronounced, at any rate in many cases, while the traces of it are universal. There is no evidence, nor is there anywhere any sign, that the Ranunculaceae have been reduced and modified from woody parvifoliate ancestors. The Nymphaeaceae, also with a primitive floral structure, have the same grandifoliate habit and vascular structure which have been retained probably owing to their having acquired an aquatic habit. I cannot agree with Henslow's view that the grandifoliate vascular structure is the result of an aquatic habit either in the plant itself or in its ancestry, for the general effect of this habit upon the vascular structure of stems, as seen in the cases of Hippuris, Hottonia, Ceratophyllum, Potamogeton, \&c., is extreme reduction and concentration of the bundles to 
form a compact mass at the centre of the stem; Nymphaeaceae have in this sense retained their primitive structure in spite of the aquatic habit, although, had they become terrestrial in habit, and developed erect woody stems, they would almost certainly have lost it. In Berberidaceae, Calycanthaceae, and Magnoliaceae, all of which have undoubtedly a primitive floral structure, the majority of plants are woody shrubs, and hence their primitive vascular structure has become largely obscured or lost, but the large, sheathing leaf-bases or stipular appendages of such plants as $\mathrm{Mag}$ nolia and Berberis Aquifolium are an obvious reminiscence of their grandifoliate origin, as is also the ranked arrangement of the bundles in the leaves of some genera. In the grandifoliate Berberidaceae, like Podophyllum, the ancient vascular structure is present in a most marked degree. The Compositae and Umbclliferae include a great many plants of grandifoliate habit ; but, as their floral structure indicates, they are groups advanced in evolution i. e. in certain special directions; hence we find that, unlike the Ranunculaceae, their primitive grandifoliate vascular structure is undergoing a great amount of modification, the scattered system of the bundles, where it occurs, being always more or less of a rudimentary nature and showing indications of extinction.

In some plants, where the grandifoliate vascular structure has vanished from the internodes, it is still preserved at the nodes which are always the least modified portions of the shoot.

Another interesting point is this: that in the bundles of the scattered medullary system the xylem always tends to surround the phloem. And this amphivasal bundle is precisely that which is characteristic of Monocotyledonous stems, although there, as in the Dicotyledonous stems I am now referring to, the amphivasal character is very often incomplete, the xylem failing to completely enclose the phloem and thereby exhibiting a V-shaped structure. The amphivasal character of the bundle in these stems is the more complete the more independent the latter is of the vascular ring; the nearer the medullary bundle approaches the ring, the more collateral and also the more regularly-orientated does it become; the bundles constituting the ring merely represent the outermost members of the scattered bundle-system marshalled and arrayed in line for the purpose of forming a cylindrical structure which shall be efficacious in resisting bending-strains in the elongating stem; every transition can, in many instances, be seen between the collaterally-constructed members of the ring and the most central and independent of the amphivasal medullary strands. The presence of a cambium, or (as happens in many cases, as where the 'internal phloem'-group is without xylem) the rudiments of such, is a very important feature of the medullary bundles in these Dicotyledons. It indicates that the latter are descended from ancestors the scattered bundles of whose stems possessed secondary thickening to 
a greater or less extent. As the more external of these bundles began to form themselves into a ring, and this latter began to increase the extent of its tissues to an ever-increasing degree by means of secondary thickening, this would tend to induce a degradation and eventual disappearance of the cambium of the medullary bundles and, finally, of the bundles themselves.

\section{RANUNCULACEAE.}

The grandifoliate habit is strongly represented in this order. They are mostly plants with a squat vegetative stem bearing large leaves. Some, as $R$. Ficaria and Eranthis, are typical geophytes having no aerial, leafy stem, but merely peduncles terminating in a flower; most, however, seem rising out of the squat habit, inasmuch as they produce a rather short, and, often, unbranched leafy stem, which, however, soon produces flowers, as in Delphinizm. The members of this order bear a close resemblance to Monocotyledons, not only in their vascular anatomy but in their habit and the structure of their flowers. But they appear to be less specialized and reduced than most Monocotyledons of the present day, and are probably in several ways and on the whole more primitive. It is on account of the primitive floral structure that I regard the prevailing grandifoliate or subgrandifoliate habit of these plants as also primitive.

\section{Anemone japonica, Sieb. \& Zucc.}

I will take this plant as a type from this order of plants retaining the, to my mind, primitive scattered or medullary bundle-system.

Leaf: In the typical part of the petiole, which is more or less cylindric, the bundle-system is radio-symmetrical ; it consists of four ranks of bundles, of which those of the two outermost ranks are, many of then, situated at the same tangential level, there being, as so often happens, some irregularity in this respect.

Several of the small outermost bundles are rudimentary, possessing either phloem and a sclerotic arc only, or only the latter, their xylem being quite absent. These same rudimentary bundles occur in Monocotyledonous stems and leaves. The innermost rank is represented by a single large bundle occupying a perfectly central position. The xylem is very V-shaped, subtending a circular phloem. This, then, is the same structure which prevails unmodified in the aerial stem. In the sheathing base of the petiole this scattered system changes gradually into that of the arc, and this takes place by the bundles on the ventral side passing across and fusing with those on the dorsal side, or assuming a position between them, at the same time revolving on their axes through $180^{\circ}$, while all the small rudimentary bundles and a few of the larger ones gradually die out completely or become more and more rudimentary towards the base of the leaf.

Aerial stem: This must be regarded as the typical and least modified y y 
part of the axis of the plant, and hence that part where the primitive vascular anatomy will be most likely to portray itself. Here we find the Monocotyledon-like, scattered system of bundles well shown. There are 3-4 ranks of bundles, though some irregularity obtains here and there. The largest and earliest-formed bundles are innermost, the bundles diminishing in size and development of their tissues from the centre of the axis outwards. Each bundle possesses a circular primary phloem-group situated in'a fork of the xylem. All the bundles are leaf-traces. A pith is present, the diameter of which is about equal to the radial distance from the protoxylem of the innermost bundles to the epidermis. There is no sclerotic zone present in the stem.

The peduncle also possesses the Monocotyledonous medullary bundlesystem, being a stoutly-developed organ.

If this plant has been derived by reduction from an aërophytic ancestor with an elongated woody stem containing a vascular cylinder with the bundles compactly grouped in one rank, one would think that the elongated leafless peduncle of this species is just the kind of organ in which such a one-ranked vascular cylinder would have been retained, unless one admits the somewhat forced idea that this peduncle has been redeveloped out of a more humble organ; but if this latter is the case how is it that the aërophytic or parvifoliate structure has not yet been acquired.

The flowering stem of $A$. rivularis, Buch.-Ham. also shows beautifully the grandifoliate or Monocotyledonous structure.

Small forms like $A$. nemorosa $L$. and $A$. apennina $L$. have probably been reduced from larger ones like $A$. japonica. There is anatomical evidence of this; for in the petioles of these species a remnant of the medullary bundle-system occurs in the form of a few small rounded phloemgroups. And in the bract-node of the stem of $A$. nemorosa I observed four very small bundles pass into the pith, there assume an inverted orientation (two of them having completely lost their xylem) and again pass outwards into the ring.

\section{Thalictrum flavum L.}

This plant affords an excellent illustration of the mode of transition in both leaf and stem-structure from the 'Monocotyledonous' to the 'Dicotyledonous' type.

Leaf: In the upper part of the petiole a complete cylinder of bundles obtains, the latter, although of three distinct sizes or primitive ranks, being all in one (rather sinuous) ring ; this is owing to the excessively wide hollow pith (Pl. XXXII, Fig. 8). Lower down, two ventral, rather filamentous wings begin to form, and two smaller bundles pass out of the ring at this point, quite on to the dorsal side of the larger bundles there situated. As the wings enlarge, small bundles, presumably arising from the division of the just- 
mentioned outlying ones, pass into them ; by further division and enlargement of the strands at the corners of the cylinder the wings become well supplied with bundles, all orientated as those on the dorsal side of the cylinder, while all the time the original cylinder of the petiole is maintained, and the pith becomes narrower and narrower. Eventually the pith becomesobliterated, and the ventral bundles of the cylinder pass across and fuse with those of the dorsal side, some of the smallest ones dying out in situ; the same thing occurs with the bundles of the wings, until finally a wide-sheathing base, enclosing the stem at the node, is formed. There is nothing special to narrate about the mode of union of the petiolar bundles with the stemcylinder.

Aerial stem: In spite of the wide hollow pith, the scattered arrangement of the bundles prevails here in marked form in the comparatively narrow zone allotted to the vascular tissue, the three ranks of bundles being very independent as regards their relative positions. The xylem is very V-shaped and the phloem pronouncedly circular. A well-marked sclerotic zone surrounds the cylinder (Pl. XXXII, Figs. 9-2I).

I will consider two more plants before leaving the Ranunculaceae, viz. Helleborus and Clematis, as they show some points of interest.

\section{Helleborus odorus, Waldst. \& Kit.}

Leaf: The ordinary horseshoe-shaped arc prevails in the petiole with a narrow gap on the ventral side. In the sub-divisions of the lamina, however, the inverted ventral bundles occur in various positions, and are fairly numerous; some very small ones lie closely contiguous to the ventral face of an arc-bundle (Fig. 7). Another one lies rather obliquely on the ventral side and some distance from the arc. I regard them as representing a vestige of the primitive cylinder.

\section{H. viridis, $\mathrm{L}$.}

Leaf: The arc of bundles here is almost closed, being very circular, the narrow gap being caused by the ventral groove of the petiole. About the middle of the organ occurs, at one end of the arc, in the case of one leaf examined, a minute bundle with inverted orientation, which lies in the lateral corner of the ventral side, and evidently represents the last vestige of the row of inverted bundles which once connected the two ends of the arc ; it dies out below ; its upward course I did not trace. The bundle at the other end of the arc is incurved, but has not gone the length of abstricting off a bundle. A ventral inverted bundle also occurs opposite a bundle near the middle of the arc in the base of one of the subdivisions of the lamina; further along the same subdivision it does not occur. About. half-way down the petiole, in one leaf examined, the two end-bundles of the. arc are perfectly concentric, with central xylem (Fig. 6); which is due. 
to the fact that each has abstricted off a bundle on to the ventral side in an imperfect manner, so that the two have remained in contact; or, stating the matter conversely, the sole remaining bundles of the ventral part of the cylinder have imperfectly assimilated themselves with the dorsal portion of the latter, each bundle having fused with an end-bundle of the dorsal arc without revolving on its axis; hence the fusion is with the entire inner face of the dorsal bundle, instead of, as is usually the case, with one side of it only. So that each concentric bundle here represents a kind of little remnant of the primitively complete cylinder. It is precisely the same phenomenon as we shall presently find reappearing in the case of the concentric bundles of Paeonia.

\section{H. niger, $\mathrm{L}$.}

Leaf: A perfectly horseshoe-shaped arc here obtains, the end-bundles of which come to lie quite on the ventral side of the petiole and are hence inverted; it is interesting to note that these tend to become obliterated, being very small; and in one case the bundle was quite rudimentary in structure, possessing a few cells of phloem only and no xylem. These facts tend to show that the arc has been derived phylogenetically from a cylinder of bundles.

\section{H. lividus, Ait.}

Leaf: The bundles of the petiole are arranged in a wide and very open arc. In passing upwards from the basal region inverted bundles appear upon the ventral side of the arc; they are mostly smaller than those of the dorsal arc, and lie close to the latter; a bundle of the arc may have two bundles lying obliquely on the ventral side, one at each side of the protoxylem; another bundle is seen with a bundle immediately on its ventral side and perfectly inverse in its orientation. In passing both into the basal region, and also upwards into the lamina, some of these bundles pass in and unite with those of the arc, others appear to die out in situ in an oblique position (i.e. at the half-way stage from the purely ventral and inverted state to union with the bundle of the arc); immediately below the lamina the two end-bundles of the arc have each an inverted ventral bundle closely connected with its protoxylem, while the vestiges of another occur further out on the ventral side.

\section{H. foetidus, L.}

Leaf: This is anatomically one of the most advanced species, as a very open dorsal arc only prevails throughout the petiole; but traces of the primaeval cylinder occur here and there, as in about the middle region of the petiole a bundle about half the size of most of those of the arc lies at one side of the inner half of the xylem of one of the arc-bundles and is orientated sideways, and is obviously in a position representing a half-way stage on its transit to the ventral side of the arc. Again, in the lamina, 
both at the base of the main blade and in the stalks of one or two of its subdivisions, a very small inverted bundle occurs on the ventral side of one of the arc-bundles. By means of these phenomena we are able to see the relationship between the leaf-structure of this species and of those which possess a cylinder.

\section{Clematis Vitalba, L.}

Leaf: In the typical part of the petiole a complete cylinder of bundles obtains.

\section{Clematis heracleifolia, DC.}

Leaf: In the typical region of the petiole is a wide arc of $12-13$ bundles. On the ventral side, and some little distance away, are about four very small inverted bundles (Fig. I4). In passing either upwards to the lamina or downwards to the leaf-base, two of these bundles fuse together to form a strand, which then, revolving on its axis, unites with a bundle of the dorsal arc; the two other ventral bundles die out in situ.

\section{C. recta, L.}

Leaf : Extending throughout the petiole is the following structure: a dorsal arc of about eight bundles, varying in size. The petiole, as also in the last species, has a deep groove on the ventral face. On either side of this groove are, respectively, one and two minute inverted bundles, evidently on the point, phylogenetically speaking, of dying out altogether. Before the dorsal arc unites with the stem-cylinder, these ventral bundles, which extend almost to the very base of the leaf, disappear, but I did not determine whether they die out in situ or unite with the dorsal bundles.

\section{C. apiifolia, DC.}

Leaf: In the typical part of the petiole is a complete, almost circular cylinder of bundles; lower down a flattening occurs on its ventral side, and the bundles thereof begin to pass across and unite with those of the dorsal side; one or two of the more lateral ones persist to the extreme base of the petiole before finally uniting with their dorsal neighbours immediately before the latter unite with the stem-cylinder. By eventual lateral fusion the latter receives three main bundles from the leaf: a median and two lateral ones.

$$
\text { C. alpina, Mill. }
$$

Leaf: This is an advanced type from the point of view of its anatomy, inasmuch as the primitive petiolar cylinder has become practically extinct, so that in both the uppermost and lowermost region merely a dorsal arc of bundles obtains; in an intermediate region, however, traces of the ancestral cylinder can be, at least in some leaves, discerned in the form of a minute ventral bundle with inverted orientation lying near one of the end-bundles of the arc from which it had presumably become detached (Fig. I5). 
In view of the presence of this ventral bundle, this species cannot be said to be so distinct in its petiolar structure from other species, as some authors, e.g. Plitt, has maintained. The petiolar structure of $C$. heracleifolia and $C$. recta is clearly transitional in character between the more primitive type of C. apiifolia and C. Vitalba, in which, in the typical part of the organ, a complete normal cylinder obtains whose bundles are all equally well developed, and the more advanced type of $C$. alpina, in which nearly, but not quite, all vestige of the bundles constituting the ventral part of the cylinder has disappeared.

We have thus briefly studied some types from the Ranunculaceae, but will postpone a discussion of the results until after the study of types from the other orders of the group has been accomplished.

\section{BiBLIOGRAPHY.}

Andersson, S. : Ueber die Entwickelang der primären Gefässbiundelstränge der Monokotylen, Bihang till K. Sv. Vet. Akad. Handl., Bd. xiii, 1888. Abstr. in Bot. Centralb]., vol. xurviii, 1889, pp. $5^{86}$ and 618.

Bastin : Cimicifuga (American Journal of Pharmacy, 1895) (not seen).

Bourgues, H. : Structure, Origine et Développement de certaines formes vasculaires anormales. du pétiole des Dicotylédones. Thèse, Bordeanx, 1902.

ClARK : Cotyledon and leaf-structure in certain Ranunculaceac. Torreya, I905.

CoL, M. : Sur les relations des Faisceanx médullaires et des Faisceaux dits snrnuméraires avec les Faisceanx normanx. Journ, de botanique, vol. xvi, no. 7, 1902.

Costantin: Etude comparée des tiges aériennes and souterraines des Dicotylédones. Ann. Sui. Nat., ser. 6, vol. xvi, 1883 .

De BARY: Comparative Anatomy of the Vegetative Organs of the Phanerogams and Ferns, 1884.

Finlayson: Stem-structure of some leafless Plants. Trans. and Proc. New Zealand Inst., igo3.

Géra RD, R. : Recherches sur le passage de la Racine à la Tige. Ann.d. Sci. Nat., sér. 6, i 881, p. 279.

GER NET : Xylologische Studien : Ueber die Structurverhältnisse des Stengels von Thaliclrum favum. Bnll. Soc. Moscon, I 861 , p. 423 .

GofFArT : Recherches sur l'anatomie des feuilles dans les Renonculacées: Archives de l'Institut bot. de l'Univ. de Liège, vol. iii, I90I, and Mém. de la Soc. Roy. d. Sci. de Liège, sér. 3, vol. ii, 1899 .

Henslow, G.: A theoretical Origin of Endogeng from Erogens by Self-adaptation to an Aquatic Habit. Journ. Linn. Soc., vol. xxix, p. 485,1892 .

Jaxczewski : Étude morpbologique sur le genre Anemone L. Rev. gén. de bot., 1898.

LENFANT : Contribation à l'anatomie des Renonculaceses: Le genre Delphinium.

Mansion : Contribution a l'anatomle des Renoncalacees: Le Thalictrum fiavam L. Archives de l'Institut botanique de l'Université de Liège, vol. i, 1897.

Marié: Recherches sur la structure des Renoncalactes. Thèse, $188_{4}$.

- : Recherches sur la structure des Renonculacés. Ann. Sci. Nat. bot., sér 6, 1885.

- MeYer, A.: Beiträge zur anatomischen Systematik der Ranunculaceen. Wigands Iłot. Hefte, vol. i, 1885.

Nestler, A.: Abnormal gebaute Gefässbündel im primären Blattstiel von Cimicifuga foetida,

Nova Acta Acad. Caes. Leop.-Carol Germ. Nat. Cur., Band Ivii, No. 1.
- Der anatomische Ban der Laubblätter der Helleboreen. Nova Acta Acad. Caes. Leop.-Carol. Germ. Nat. Cur., Band lxi, No. I, 1893.

- : Der anatomische Ban der Laubblätter-der Gattung Ranunculus. Nova Acta Acad. Caes. Leop.-Carol. Germ. Nat. Car., Band lxiii, I895.

Ninozt: Contribution à l'étude anatomique des Renunculacées, $R$. Arvensis. Mém. in-4 pub. par l'Acad. roy. des sci., des lettres et des beaux arts de Belgique, vol. lii, 1891 . 
Parmentier, P.: Kecherches sur les Thalictrums de France. Bull. Sci. de la France et de la Belgique, vol. xxvii, sér. 4, 1895 .

Petit, L.: Le pétiole des Dicotylédones au point de vue de l'anatomie comparée et de la taxinomie. Thèse, Bordeanx, 1887.

Piccone : Foglie delle Ranunculacee. Atti della Soc. Ital. di Scienze, vol. rxxiii, i889.

PlitT: Beiträge zur vergleichenden Anatomie des Blattstiels der Dicotyledonen. Diss., Marburg, 1886.

QuÉva, C.: Contribations à l'anatomie des Monocotylédones. Trav. et Miém. de l'Univ. de Lille, 1900.

RESvoll: Nogle arktiske ranunkler morfologi og anatomi. Nyt Magaz. for Naturvidenskab, 1900.

Sargant, Miss : A Theory of the Origin of Monocotyledons, founded on the Stracture of their Seedlings. Annals of Botany, vol. xvi, Jan., I9\%3.

- The Evolution of Monocotyledons. Bot. Gaz., vol. xxivii, May, I904. April, 1908 .

SARton: Recherches expérimentales sur l'anatomie des plantes affines. Ann. Sci. Nat., sér. 9, vol. ii, 1905 .

Sterck, R.: Recherches anatomiques sur l'embryon et les plantules dans la famille des Renonculacées. Mém. de la Soc. Roy. d. Scl. de Lì̀ge, sér. 3, vol. ii, 189. de l'Institut botanique de l'Univ. de Liège, vol. i, 1897.

Vesque : De l'anatomie des tissns appliquée à la classification. Nouv. Arch. d. MIns. d'Hist. Nat., sér. 2, vol. iv, $188 \mathrm{I}$.

ZiEgler : Uber den Verlauf der Gefässbiundel im Stengel der Ranunculaceen. Diss., Erlangen, 1895.

\section{PAEONIACEAE.}

For the reasons which have induced me to place Paeonia, usually regarded as a member of Ranunculaceae, in a separate, independent order, I refer the reader to my article on the subject in the Journal of Botany. The vascular structure of the leaves and stem is very much more like that of Magnoliaceae than that of Ranunculaceae.

\section{Paeonia, sp. (herbaceous type).}

Leaf : the petiole contains a horseshoe-shaped arrangement of the bundles, consisting of a large median bundle, two large lateral ones adjacent to it, and two or three smaller ones at either end of the arc; in the upper part of the organ, owing to the incurving of the bundle-arc, an almost complete cylinder is formed (Figs. 19, 20). In the very base of the petiole, whose tissues are already in intimate union with those of the cortex of the stem, the two (2-4 in some species) large lateral bundles, which by this time have become considerably curved in contour, separate off each a bundle which rotates on its axis, assuming thereby an inverted orientation, and takes up a position on the ventral side of the bundle from which it separates; the whole subsequently, by intimate union of the two mutuallyinverted parts, becomes a concentric bundle, consisting of external phloem and internal xylem; or the ventral may never actually separate from the dorsal portion, but the whole strand becomes incurved and finally concentric. From the smaller bundles of the horseshoe, also, minute bundles, 
which become inversely orientated, are separated off (Figs. 2I, 22); some of these die out below - a fact, coupled with that of their minute and insignificant size, which proves their vestigial ancestral character; others pass in arid unite with the stem-cylinder. At about this time also the large median bundle of the petiole unites with the stem-cylinder, followed shortly after by the two which are second in number from each end of the arc. The two large concentric bundles are the last to join the stem-cylinder, for before doing so they pass a considerable distance down the internode, forming the characteristic cortical bundles of this plant.

My interpretation of the above structure is this: that the extreme basal portion of the petiolar bundle-system containing the concentric bundles $^{1}$ and the minute inverted bundles alone represent the primitive cylindrical structure. The cylindrical structure occurring in the upper part of the petiole, which is formed by incurving of the ends of the dorsal arc of bundles, I regard as a secondary phenomenon. If our knowledge of events was confined to Paeoniaceae alone, we should never be able to recognize in the concentric structures the passage from the primitive cylinder to the dorsal arc of bundles; it is only by comparison with similar structures in the closely allied order Magnoliaceae and the allied genus Helleborus (see above) where transitional stages are available for our observation, that we are able to interpret the facts in Paeoniaceae in the same way as I have done in the case of the concentric petiolar bundles of Helleborus. It is certainly interesting to find that the cylindrical structure of the upper or typical portion of the petiole of Paconia is not strictly homologous with that of the petiole in Ranunculaceae, Magnoliaceae, and Anonaceae, but is secondarily derived. However, another mode of interpreting this structure may be as follows : that the same primitive cylindric conformation constituting the extreme base of the petiolar system, viz. in the stem-cortex, after completely disappearing for a time as we pass upwards, the dorsal arc of bundles only existing there, reasserts itself in the upper or typical region of the petiole; or that the primitive structure of the upper part of the petiole reasserts itself in the cortex of the stem. The comparatively narrow free base of the petiole, in the great majority of plants, scems to show the mechanical necessity of the presence there of a dorsal arc of collateral bundles; in the cortex of the stem, in the region where the leaf-base forms part of the latter, this mechanical necessity does not, probably, arise; hence the partial assertion there of the primitive cylindric structure; the reassertion of this primitive cylindric structure occurs in the upper or typical part of the petiole; but it is there brought about by a somewhat different constructive agency than is the case with that part of the system which is in the stem; yet this cannot prevent our regarding the

1 Paconia shows its alliance with Calycanthaceae in the fact that the veritral portion of the primitive cylinder does not occur in the leaf proper bat only in the cortex of the siem (see inf ra). 
two structures as essentially two, for physiological purposes, interrupted parts of one and the same primitive and ancestral cylinder.

The leaf-base more than half embraces the stem; this character, together with the large size of the petiole-bundles as compared with those of the stem, clearly give the impression of the leaf being the more important of the two organs, viz. the one which is likely to have given character and origin to the other, rather than the reverse.

In the peduncle, concentric bundles constitute the only foliar-traces; some of them are large, others are very small; they leave the cylinder as arc-shaped strands, which soon close up and enclose a pith (Fig. 23). They eventually enter the sepals of the flower, each breaking up into a number of collateral bundles. Their interpretation is the same as for the vegetative stem.

\section{BIBLIOGRAPHY.}

Goffart : loc. cit. Meyer : loc. cit. Petit : loc. cit. Sterck : loc. cit.

\section{MAGNOLIACEAE.}

In spite of the fact that the plants of this order are trees and shrubs, there is considerable evidence, both in the external morphology and the internal vascular anatomy, that the entire stem is built up of a succession of phytons, each segment having primarily terminated in a leaf. The large size of the leaves, the way their petiole-bases, by means of their stipules, completely embrace the stem, point to the fact of the leaf having been the dominant organ of the plant, to which the stem was subservient. This is well brought out, as will be seen below, by the study of the vascular structure of stem and leaf.

In the preservation, in the young stem, of the individuality of the bundles of the cylinder, and in their somewhat irregular size and arrangement, we see traces of the primitive scattered system in the central cylinder. Hence I conclude that the arborescent habit of the plant is derived and not primitive.

\section{Magnolia tripetala, L.}

I will take this species as typical of the genus.

Leaf : In the midrib of the lamina is a complete cylinder of bundles. About half-way down the petiole five or six of these bundles pass into the pith and remain there, all situated on the dorsal side, until such time as the petiolar strands enter the stem; this structure is probably a reminiscence of the primitive scattered system of the herbaceous ancestor.

Stem : At the junction with the stem these medullary bundles again fuse 
with the petiolar cylinder. When this has happened the bundles forming the ventral half of this cylinder begin to pass across and unite with those on the dorsal side; this, however, is not completely effected until some considerable distance down the internode of the stem, and long after all trace of the petiole-attachment has vanished. We note the presence in the cortex of the stem of a bundle-system consisting of two or three ranks of strands (as seen in all species of Magnolia), some of which are concentric, others arc-shaped, others again with inverted orientation.

Peduncle: In this organ the modifications have not been so great as those in the vegetative stem; there are clearly three ranks of bundles forming, within a limited area, a scattered system of strands. A difference from what usually obtains in stems is here noted, viz. that the largest bundles, which are the latest incoming leaf-traces, are outermost, and the smallest innermost, the bundles of the two sizes alternating with each other. They are all very narrow in the tangential direction. In the cortex occur concentric or partially concentric strands arranged in a single ring; their xylem is internal and the phloem external. In the grourd-tissue occur sclerotic groups of cells. Between the above-mentioned cortical bundles and those of the central cylinder, and apparently linking up into one the two otherwise distinct systems, is a ring or rank of arc-shaped collateral bundles whose shape is obviously intermediate between that of the bundles of the cortical system and that of those of the cylinder. These represent the components of the dorsal arc which only at this late stage exhibit the completion of the process of union with the ventral strands of the petiolar cylinder (Fig. 33, Liriodendron).

The other species in which I found medullary bundles in the petiole are $M$. macrophylla, Michn., $M$. acuminata, L., $M$. grandiftora, L., $M$. conspicua, Salisb., M. Campbellii, Hook. f. et Thoms., and M. Watsoni, Hook. f.; in the last named, two or three bundles from the dorsal side of the cylinder seem to make a half-hearted attempt to become medullary, but they scarcely leave the cylinder, although they are situated further towards the ventral side than are the other larger bundles of the cylinder.

In Talauma Hodgsoni Hook. f. the medullary bundles, which have a very $\mathrm{V}$-shaped xylem, appear in the swollen petiolar base; they emerge from the cylinder on its dorsal side and re-enter it in the extreme base of the organ on its ventral side. The ventral bundles here fuse up together to form two or three large bundles which, revolving on their axes, enter the stem-cylinder independently.

In Liriodendron one bundle of the cylinder of the petiole tends to become medullary; at the extreme base the ventral bundles anastomose with the dorsal, the lateral bundles (about two on each side) remaining free and unchanged. There is no persistent cortical leaf-trace system as in Magnolia, the change from leaf- to stem-structure taking place more rapidly. 


\section{Drinnys Winteri, Forst, and D. aromatica, F. Muell.}

Leaf: Three large bundles, widely separated, occur in this organ; between two of them, in the case of $D$. Winteri, occurs a tiny bundle and at one end of the arc a minute imperfect bundle which is evidently on the way to extinction. The presence of these sinall, dwindling bundles seens to point to a former greater development and extension of the arc to constitute part of a complete cylinder. The somewhat arched character of the larger bundles also seem to point to a time when they were in the habit of abstricting off bundles on the inner side to constitute a medullary system. The arc unites directly with the stem-cylinder. This genus is closely allied to Illicium. These plants have the most modified and advanced floral structure of any in the order ; it is interesting, therefore, to find a corresponding and parallel advance in the vascular structure.

\section{D. amplexicaulis, Vieill.}

Leaf: In the extreme top of the petiole immediately below the lamina and in the midrib of the latter (the only parts of the leaf I was able to examine, and even that in the form of herbarium-material only) there is a dorsal arc of four or five bundles situated at wide distances apart. There is also a medullary system of three or four bundles which are but little smaller than those of the arc; they are situated at varying depths, but none are very far from the arc; they are also orientated in the same manner as the arc-bundles, although one or two lie rather obliquely. Some way up the midrib the arc-bundles are almost concentric, becoming very much inarched, which is probably due to their possessing the characteristic of abstricting off medullary bundles ${ }^{1}$; in close proximity to one of these on the ventral side were two dorsally-orientated small bundles.

The medullary bundle-system does not occur in the two species above described, either in the petiole or lamina, and I am unable, through lack of material, to say whether it occurs throughout the petiole of this species. It must be regarded as a primitive character and its occurrence in this species is probably an index to what must have been the ancestral character of the entire genus. D. amplexicaulis is thus more primitive in the vascular structure of the leaf than $D$. aronatica and $D$. Winteri.

\section{Illicium floridantm, Ellis.}

Leaf: A single arc-shaped bundle which unites directly with the stem-. cylinder; this may be regarded as the most highly-modified and most

1 This idea is a purely artificial one; phylogenetically speaking, I hold that precisely the reverse process is taking place, viz. fosion of the medullary with the arc-bundles. 
recent of the vascular structures in this order; neither stipules nor sheathing leaf-base occur (Figs. $3^{1}$ and $3^{2}$ ). In the structure of the petiole the Illicieae or Winteraceae section of this order shows a certain resemblance to Calycanthaceae, but owing to the absence of any cortical system of bundles they are much more modified and advanced than this latter group.

I need not here occupy space with a description of the remaining genera, as they exhibit nothing of special interest.

\section{BIBLIOGRAPHY.}

Miatsuda, S.: On the Anatomy of Magnoliaceac. Jonm. Coll. Sci. Imp. Univ. Japan, vi, 1894 Parmentier, P.: Histoire der Magnoliacées. Bull. Sci. de la France et de la Belgique, vol. xxvii, sétr. $R, 1895$.

Petit, L.: Le pétiole des Dicotylédones an point de vae de l'anatomie comparée et de la taxinomie. These, Bordeanx, 1887 .

Plit : Beiträge zar vergleichenden Anatomie des Blattstiels der Dicotyledonen. Diss., Marbarg, 1886 . SOLEREDER : loc. cit.

Vesque: Les tissus régétaux appliqués à la classification. Nour. Arch. d. Mus. d'Hist. Nat., sér. 2, vol. iv, I88r.

\section{CALYCANTHACEAE}

Stein ${ }^{1}$ : As regards the cylinder there is nothing special to narrate, the peculiarity of this stem is the presence of the four 'cauline' cortical bundles with inverted orientation of their parts (Fig. 25). Starting from a typical region of the axis and tracing the vascular system upwards we find on approaching a node that the four cortical bundles begin to divide up in the tangential direction, the two on one side of the stem (corresponding to the two opposed edges of two distinct leaves) being far ahead in this procedure of the two on the opposite side. A large bundle passes off from the cylinder to form the main strand of the leaf. This then gives off a bundle which joins the dividing cortical bundle. From the latter a bundle is now given off at right angles to form one of the lateral bundles of the leaf. Both cortical bundles on the same side then divide up greatly to form a single continuous lengthy strand which constitutes a horizontal connexion between them. Then a second bundle, smaller than the first one, is given off to the lateral region of the leaf, and at the same time a phloemstrand is seen running up towards the midrib-bundle; this is a strand joining the axillary bud-bundles. Both xylem and phloem of the middle region of the horizontal connexion then die out, with the result that the two cortical bundles of that side remain over for the next internode above.

Immediately subsequent to this the same sequence of events occurs on the opposite side of the stem.

1 The entire description bere giren is equally true for both genera, viz. Calycanthus and Chimoranthus, and for all species of either. 
From the above it will be seen that each leaf, besides the large midribstrand, receives four bundles (two on each side) from the cauline inverted strands of the stem.

Essentially the same facts were observed in the case of the seedling plant; it would appear, however, that the cauline bundles are rather late in making their appearance, for in the region where the cotyledonary bundles have left the cylinder, but where the cotyledons themselves are not yet detached as distinct organs, there is no sign of the four cauline bundles. But these latter soon after arise from the cotyledonary traces; or, in other words, they pass downwards from the first pair of foliage-leaves above and unite with these traces.

The facts above detailed are usually interpreted as follows: that each cortical bundle is built up by the lateral bundles of one-half of each leaf (the main midrib-bundle passing directly into the cylinder), which on entering the stem at once unite with a similar leaf-trace descending from the node above. These 'leaf-traces', then, never unite with the stemcylinder at all, but constitute an independent cortical system. As was the case also with Lignier and Van Tieghem, I was unable to discover any nodal connexion between the cortical bundle and the stem-cylinder, such as Woronin describes; this connexion is effected solely by the midribbundles.

Baillon describes a Chimonanthus-stem whose leaves (except those, as in the case of some shoots, at the base, which were opposite) were arranged on the shoot according to a $\frac{2}{5}$-spiral, while, in accordance herewith, there were five cortical bundles; this may be regarded as of the nature of a reversion to the primitive condition, for it is interesting to note that the peduncle of both genera, which bears spirally-arranged foliar organs, has from six to eight cortical bundles which are in five groups (i. e. at two points a pair of bundles occurs). The probable physiological explanation of the presence of these persistent and independent 'leaf-traces' which I would advance is that they serve to give rigidity at the four necessary points to the angles of the quadrangular stem, and have been preserved for this purpose; the same phenomenon of cortical strands occurring in such a position is seen in the square stems of Labiatae, Melastomaceae, and other plants.

\section{BIBLIOGRAPHY.}

Balllon: Sur un Chimonanhws à feuilles alternes. Adansonia, vol. ix, 1868-7o.

CrUgrr: Anomale Holzbildangen. Bot. Zeit, p. $48 \mathrm{I}, 185 \mathrm{I}$.

DE BARY : loc cit.

Gaudichaud : Arch. de Bot., rol. ii, 1833 .

HeqaIl: Recherches sur l'anatomie comparée des tiges chez les Dicotylédones.' Ann. Sci. Nat., sćr. 7., rol. ii, 1888 . 
Ligniar : Recherches sur les massifs libéro-ligneax de la tige des Calycanthées, etc. Bull. Soc. bot. de France, vol. xxxi, sér. 2, vol. vi, 1884 .

: Recherches sur l'anatomie comparée des Calycanthées, etc. Arch. sci. da Nord de la France, $1886-7$.

Mirbel : Tige d'un très vieux Calycanthus floridus. Ann. Sci. Nat., sér. I, vol. xiv, 1828.

PLITT : loc. cit.

SOLEREDER : loc. cit.

Van Tirghem : La stractare de la tige des Calycanthaceses. Ann. Sci. Nat., sér. 8, vol. xix-xx, I 904 . vol, i, 1905.

Treviranus: Bot. Zeit., 1847 , p. 377 .

VESQUE : loc. cit.

Woronis : Der Bau des Stammes von Calycanthus. Bot. Zeit., 1860, p. I 77 .

\section{ANONACEAE}

The vascular structure of the plants of this order shows clear relationships with that of the Magnoliaceae and Paeoniaceae.

\section{Artabotrys odoratissimus, $\mathrm{R}$. $\mathrm{Br}$.}

Stem: Three leaf-trace bundles leave the central cylinder, but not all simultaneously; one of the laterals first passes out and then the other one ; finally the median bundle; one of the two laterals (the first to leave the cylinder) is at first three parts concentric in structure and later becomes wholly so; the other lateral does not become completely concentric. The median bundle splits into three.

Leaf: As these bundles pass into the leaf the two laterals open out, become quite collateral, and fuse with the two bundles which are the result of splitting of the median bundle. Hence once again three bundles. These, in the upper part of the petiole are three parts concentric, one of the two laterals having hard and soft bast along part of its ventral side. In the lamina the three are fused together into a 3 -lobed mass with a sclerotic sheath surrounding the whole, which is perhaps, along with the ventral phloem just mentioned, a reminiscence of a primitive cylinder of bundles possessed by the leaf; while the concentric or sub-concentric bundles in the base of the petiole and stem-cortex probably represent a second partial attempt at reversion to the cylindric structure.

\section{Polyalthia suberosa, Benth. and Hook.}

Leaf: In the upper part of the lamina is a very much flattened, undulated cylinder of bundles in which is a gap at each lateral angle; the dorsal segments of this cylinder show a tendency to round off into individual concentric strands; in the lower part, near the top of the petiole, the midrib cylinder splits into three parts, of which the middle bundle is quite 
concentric, the two lateral horseshoe-shaped, one of which still retains phloem on the ventral side and the other one phloem on part of that side only; both of them still retain the bast-fibres on that side.

In the upper part of the petiole one lateral exhibits concentric structure with a small inverted ventral segment detached, as if about to pass away from the main strand; the other lateral and the median bundle have a gap on the ventral side; the latter bundle has a small strand belonging to the gap some way out on the ventral side; lower down is an arc of about five collateral bundles.

Sten : By subsequent fusion three bundles are eventually left which unite with the stem-cylinder, the large median one doing so first and then the two laterals (Figs. 34-37).

\section{Eupomatia Bennettii, F. Muell.}

Leaf: There is an arc of several (about seven) collateral bundles throughout the organ.

\section{Monodora Myristica, Dun.}

Leaf: There is an arc of collateral bundles throughout; in the upper part of the petiole are three large bundles, the two lateral of which tend to round off somewhat. These arc-shaped bundles (as in the case of all such leaf-bundles wherever they may occur) are due to fusion between the lateral bundles of the dorsal side and a bundle or bundles passing across from the ventral side, these latter being a vestige of the ventral part of a primitive cylinder. (Cf. the concentric and sub-concentric bundles of Artabotrys, Polyalthia, Paeonia, Berberidopsis, \&c., all of which represent identical structures and have the same explanation.)

\section{Uvaria zeylanica, L.}

Leaf: In the lamina is a complete cylinder in which the bundles are not individualized; it is much flattened on the ventral, and convex on the dorsal side (Fig. $3^{8}$ ) ; in the upper part of the petiole a small gap begins to appear in the middle region of the ventral side, which is barely bridged, i. e. phloem only occurs in that place; a similar gap appears on one side of the cylinder near the angle between the dorsal and ventral parts. Passing downwards both these gaps become accentuated; in the second, gap above mentioned a small bundle then arises de novo; shortly afterwards connexions take place between the ventral part of the future lateral bundle of that side and the small bundle in the gap; then the former splits into. two, of which one part fuses with the small bundle which arose in the, gap; and then these two, along the part of the cylinder at the angle, go to form the lateral arc-shaped bundle, while the other part fuses with the arm of that side of the large dorsal part of the cylinder. The same thing 
occurs on the other side of the cylinder, but not quite contemporaneously. At the base of the petiole are three bundles arranged in an arc and widely separated-a transversely elongated convex median and two arc-shaped lateral bundles.

\section{Cananga odorata, Hook $\mathrm{f}$.}

Leaf: In the petiole and lamina of this plant (of which I had only herbarium-material at my disposal) medullary bundles (3-4 in number) occur ; they are approximated to the dorsal arc, as in Magnolia, are orientated in the same way as the bundles of the arc, and do not occur far away from it ; they have a distinct tendency to assume a concentric structure, with central phloem (Fig. 40). This is the only case I observed of medullary bundles in the leaf of Anonaceae, and is, therefore, extremely interesting and important. Guillard observed the same phenomenon and it was his note which suggested my own investigation.

In the peduncle of Uvaria Narum, DC. ${ }^{1}$, the bundles of the cylinder are irregular in position and size, each with a large sclerotic dorsal cap. The bundles are arc-shaped. The pith is full of minute, rudimentary bundles, each consisting only of a circular phloem and no xylem ; in one place near the cylinder is a transitional form between these medullary bundles and those of the cylinder in the form of a bundle having its phloem partially enclosed by xylem; another small bundle, with a very small group of vessels, was approximated to, and lying at an angle with, a bundle of the cylinder (Fig. 39). The above facts seem to show that the medullary system of bundles is an ancestral or vestigial character which, for some reason or other, has persisted in the peduncle while having vanished from the stem; it is probably to be regarded as a relic of the monocotyledonous scattered arrangement of the bundles. In a peduncle of this species from the Kew Herbarium I could, however, find no trace of the medullary bundle-system ; this character may, therefore, vary with the individual; neither does it occur in the peduncles of U. excelsa or U. Kirkii.

In the peduncle of Melodorum verrucosum, Hook. f., the bundles of the cylinder are few, large, and horseshoe-shaped. A few (two or three) medullary bundles occur; they are small, obscure, and of diverse orientation; occasionally one appears at the end of one of the incurved limbs of a large bundle of the cylinder. This fact throws light on the reason for the arcor horseshoe-shaped contour of the bundles of the cylinder in this plant and also in the genus Uvaria; it probably arises owing to constant union, either in the past or present, between the bundles of the cylinder and those of the pith.

The structure of the leaf in this order shows distinct affinities both with

1 A specimen of which was obtained from Kew Museum, No. I. 
that of the leaf of Paeonia and of Magnoliaceae; with the former through the two distinct traces of the primitive cylinder in the lower and upper parts of the petiole respectively. In some genera the same formation of concentric bundles occurs, as in Paeonia and Berberidopsis, and these may almost certainly be interpreted in the same way as in those genera. The presence of what are undoubted representatives of medullary bundles in the leaf of Canainga are a perfect replica of the structure in the leaf of some species of Magnolia; as in the latter, the vascular structure of the leaf of Cananga has taken a half-way stride, as it were, towards ceasing to repeat the phylogenetic character of genuine typical medullary bundles, i. e. at each evolutionary stage the medullary bundles are being set back more and more from the pith into the rank of dorsal arc-bundles, and in the structure of the present-day Cananga, as in the Magnolias, we see a transitional stage represented. The other primitive 'character, viz. the cylindric structure, seems to have disappeared from the leaf of this plant.

\section{BIBLIOGRAPHY.}

Guillard: Singalière composition de la pervure donale dana le Cananga. Adansonia, vol, ix, $1868-70$.

\section{BERBERIDACEAE.}

The primitive floral parts of this order find their counterpart in the vascular anatomy which, in my opinion, is also markedly primitive.

I will first consider one of the herbaceous members of the order, viz.:-

\section{Podophyllum peltatum, L.}

This is one of the best examples in the vegetable kingdom of a plantorganization in which the leaf appears to be the most important and all-dominating vegetative organ of the plant; in this case, at any rate, the stem is entirely subordinate to the leaf and the vascular structure of the latter clearly gives origin to that of the former.

Fl. stem: Of the 3-4 ranks or rings of bundles here present, the outer one-to-two series are entirely foliar and pass out into the two large leaves. The second ring from the centre splits, its bundles each dividing and sending each a branch into the leaf of that side; there are thus left two ranks or irregular rings of bundles, an inner one of large, an outer of smaller bundles which are continuous up into the peduncle, and are doubtless used up in supplying the floral foliar organs (Fig. 4I).

Diphylleia cymosa, Michx., has practically the same structure as the last plant ; in the peduncle is an external rim of sclerenchyma with the smallest bundles attached to it. 

by me.

The same is true of Jeffersonia and Leontice, genera not examined Epimedium pinnatum, Fisch.

In the petiole the scattered arrangement of the bundles of the cylinder is well marked ; there are two ranks; the V-shaped character of the xylem is so extreme in some cases that the phloem is almost enclosed by it (Fig. 42).

In the stem the ranked arrangement is almost obliterated.

\section{Berberidopsis corallina, Hook. f.}

Petiole: In the upper part of this organ there is a complete, transversely elongated cylinder in which no separate bundles can be distinguished. At a lower level one end of the cylinder, followed immediately after by the other, separates and rounds off as a distinct, perfectly concentric bundle with external phloem, the xylem on the ventral side of which is much less thick than that on the dorsal side. At the base of the petiole are three bundles: a central horseshoe-shaped, and two lateral concentric ones : these latter again become collateral in the cortex of the stem; and all three unite directly with the central cylinder of the latter (Figs. 45-47).

\section{Akebia lobata, Dcne.}

Petiole: The numerous bundles form a complete cylinder; at the base of the organ the ventral bundles pass across and fuse with the dorsal ones; eventually three greatly arched, subconcentric bundles unite with the cylinder.

\section{Nandina domestica. Thunb.}

Petiole: The bundles are pronouncedly V-shaped, are in three sizes and more or less scattered, the largest lying innermost; the organ is large and cylindrical (Fig. 43).

Stem: The bundles are much less scattered than in the petiole; a comparison between the two organs in this respect is interesting (Fig. 44).

As regards the other plants of this order, their vascular structure has become much modified away from the primitive type, although the latter can be traced everywhere. For instance, in Berberis Darwinii Hook. the primitive vascular cylinder of the petiole has become reduced to an arc; in the petiole of Epinzedium alpinum, L., the ranked arrangement of the bundles is much less distinct than is the case with the species above described, although the V-shaped character of the xylem is quite as pronounced.

\section{Berberis Aquifolium, Pursh.}

Leaf: The cylindric petiole has a complete ring of nine bundles which becomes flattened on the ventral side lower down where the organ is marginally winged; as the sheathing base is formed the ventral bundles 
pass across and fuse with those on the dorsal side, the leaf-base almost completely encloses the stem, and its median bundle, which is three or four times the size of the others, is the first to join in the stem-cylinder (Figs. 49-52).

\section{Hydrastis canadensis, L.}

This plant appears to me more allied to Berberidaceae than to Ranunculaceae, hence I prefer to include it here. The morphological and anatomical structure is exceedingly like that of Podophyllum. In the flowering stem is the same scattered monocotyledonous vascular system consisting of three ranks of bundles, which tend to become confused here and there; some of the bundles of the middle rank are larger than those of the inner rank. The same structure occurs in both peduncle and petiole (Fig. 48).

\section{BIBLIOGRAPHY.}

Bastin: Stracture of Podophyllum, Amer. Joum. Pharmacy, i 896.

Col: Recherches sur la Disposition des falsceanx dans la tige et les fenilles de quelques Dicotylédones. Ann Sci. Nat., sér. 8, vol. xx, 1904, p. ir6.

Hоцм, Тн. : Podophyllum peltatam: a morphological study. Bot. Gazette, vol, xxvii, 1899, p. 419. PlitT : loc. cit.

VESQUE: loc. cit.

\section{Discussion on the Vascular Structure of the above Orders.}

A comparative study of the essential and general features of the vascular structure of these orders has, for my own mind, at any rate, thrown no small amount of light, not only on the vascular structure of the group as a whole, but also on certain peculiar and characteristic features of some of the orders of which no explanation has hitherto been forthcoming. And yet these characters are surely of sufficient interest and peculiarity to warrant the awakening of some curiosity as to their meaning and origin. It is high time we ceased to be content with the mere observation and recording of structures, and endeavoured to probe into their essential nature and relationships. The first point which accrues as a result of my study of these orders is that the primitive and original vascular system of the leaf and, consequently, that of the stem as (on the phyton theory which I uphold) a product of that of the leaf, is the complete cylinder of collateral bundles enclosing a medullary system of strands primitively amphivasal in structure. This structure we find preserved in its pristine purity ${ }^{1}$ in certain Ranunculaceae and Berberidaceae, plants which are also primitive as regards the structure of their floral organs. In the Ranunculaceae we can trace the steps by which this original structure has become modified, both in the stem and leaf. The scattered or medullary system disappears first

\footnotetext{
1 But the amphivasal bundle-structure has for the most part been lost.
} 
of all from the stem and is replaced by a hollow cylinder of bundles arranged in a single ring or rank; later on this also vanishes from the leaf leaving a similar hollow cylinder, which in its turn may become reduced to a mere dorsal arc of bundles. In the other orders the medullary system of bundles has largely disappeared; yet we see most evident relics of it in the peduncles of certain Anonaceae and distinct traces yet remaining in the petioles of some Magnoliaceae and Berberidaceae. In these two latter orders we are able beautifully to trace the steps by which the complete cylinder of the petiole has degenerated into a dorsal arc of strands, in some genera all signs of the former having completely disappeared (Text-fig. 2).

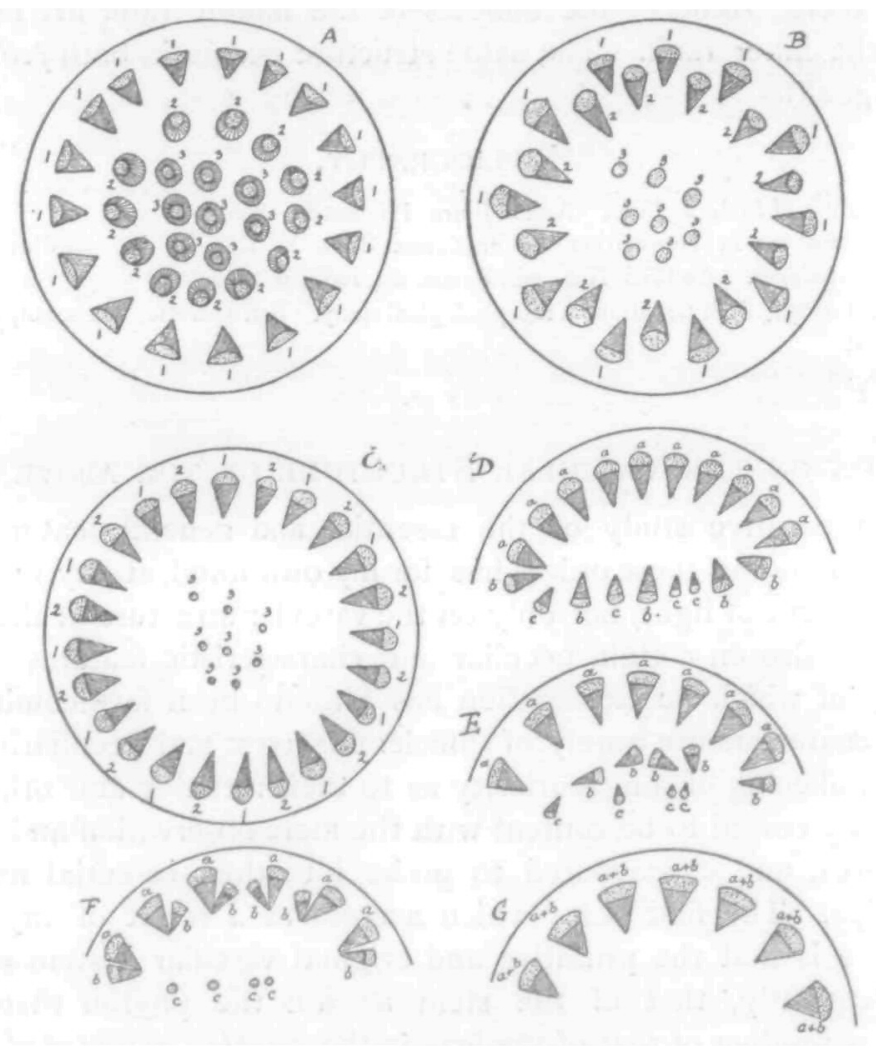

TeXT-FIG. 2.- Schematic representation of the stages in the evolution of the petiolar vascular structure in Dicotyledons $A-C$ will also apply to the stem. $A$ is not quite the earliest stage. Numerows variants of this typical general scheme occur.

The undeveloped, imperfect structure of the medullary bundle system, as also, so often, of the ventral portion of the petiole-cylinder, as compared respectively with that of the vascular ring and the dorsal part of the petiole-cylinder, is an index to their vestigial ${ }^{1}$ character; and this is the

1 If the ventral portion of the cylinder were not an ancestral character, dae to the essentially 
proof, or at any rate, a large part of the proof, which is needed to show that the medullary or scattered system, along with that of the complete vascular cylinder, represents for both leaf and stem the primitive and original structure from which all others have been derived. In the Calycanthaceae the dorsal arc of bundles in the petiole is normal and constant for the order, and hence this group may be said to be the most modified and recent of all as regards its actual petiolar vascular structure; this, however, has not been followed by a corresponding advance in the floral structure, which remains one of the most primitive. Yet I shall presently show reason to believe, from a study of the real nature of the cortical bundles of the stem, that the real and essential petiolar structure is not so primitive as appears at first sight.

As a result of this comparative study, we are also now able to explain the peculiar and characteristic cortical bundles of Magnoliaceae and Paeoniaceae, as well as the famous inverted cortical strands of Calycanthaceae.

The concentric bundles of the two former orders are seen to be merely

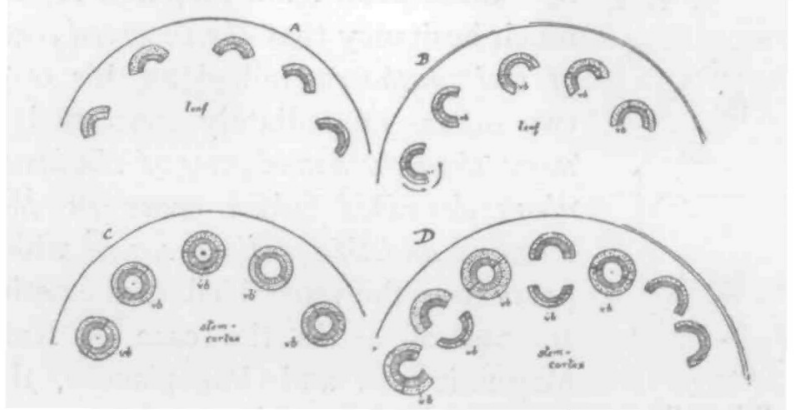

TEXT-FIG. 3.-Schematic representation of part of the petiolar vascular stracture of Paeonia $(A-C)$ and Magnolia $(D)$, showing phylogenetic origin of the concentric bundles from union of bundles belonging to the dorsal and ventral portions of the primitive cylinder of the leaf. $v b=$ bundle of ventral part of cylinder.

the expression of an imperfect transition from the complete cylinder to a simple dorsal arc of bundles, for all intermediate stages have been observed between the approach (in the base of the petiole or the cortex of the stem) of the inverted ventral bundles of the cylinder to those on the dorsal side and their imperfect union with the latter to form the concentric strand ; complete union, such as occurs in the majority of plants, consists not only of fusion but at the same time of a revolution through $180^{\circ}$ on the part of the ventral bundle to form with the dorsal one a single collateral strand, one side only, of course, of each bundle being concerned in this process. In the cortical and petiolar bundles of Magnoliaceae and Paeonia and in the petiolar bundles of some Anonaceae and Berberidopsis fusion terminal position of the leaf, and which is gradually being lost, there pould be no diminution in size or extinction of the bundles composing it as they gradually appronch the base of the leaf. 
between the two has occurred but not the complete revolution of the ventral bundle, and union of both sides of each bundle obtains to form the concentric structure as we see it. In the cortex of some Magnoliaceae all transitions towards the completion of this union may be observed-perfectly concentric, three parts concentric, and both normally and inverselyorientated collateral bundles being present (Text-fig. 3). Some of these latter, as is also the case in Paeonia, die out in the lower part of the internode without ever taking part in the union with other bundles to form the leaf-traces which unite with the stem-cylinder. In the peduncle of Magnolia Soulangeana is an outermost rank of very small and variously; but for the most part, inversely-orientated and rudimentary bundles, which doubtless, although I did not trace them, die out below; they had probably emanated from the sepals. Both in Magnoliaceae and Paeonia the concentric bundles are much more typical and in evidence in the peduncle than in the stem.

After a minute and careful study of the vascular system of the orders

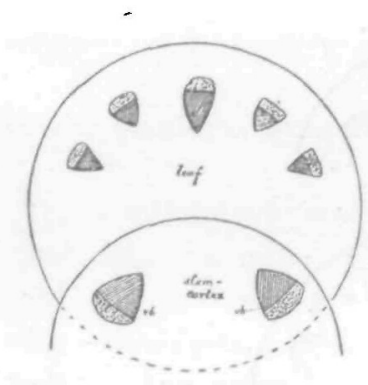

TEXT-FIG. 4.-Schematic representation showing the petiolar vascular structure of Calycanthaceae. $v b=$ bundle of ventral portion of primitive cylinder. now dealt with, I am prepared to affirm without much hesitancy that the inverted cortical bundles of Calycanthaceae (allied as this order is to the two others immediately concerned) are nothing more than the homologues of the inverted bundles aboze described which occur in the cortex of Paeonia and Magnoliaceae, and which represent portions of the ventral half of the petiole-cylinder. Instead of, as in the case of Ranunculaceae, Magnoliaceae, and Paeoniaceae, these ventral bundles either uniting with the dorsal strands of the leaf-cylinder or dying out in the internode of the stem, two of them from each leaf ${ }^{1}$ persist in an enlarged form as independent cortical bundles in the stem, never passing into the central cylinder. In the cortex of the peduncle, however, concentric bundles occur, and we may interpret them morphologically as being due to incomplete fusion between the dorsal and ventral bundles of the leaf-cylinder.

The proof that the cortical bundles of Calycanthaceae are homologous with the inverted cortical bundles of Magnoliaceae, the meaning and origin of which we know, is afforded by the peduncular structure of both orders, a glance at which is enough to convince us that this pednncular structure in both orders is homologous throughout, both as regards the central cylinder and the concentric and other cortical bundles. As in the case of each of the petiolar concentric bundles of Paeonia, each cortical bundle in Calycanthaceae is derived (but phylogenetically, not ontogenetically, as we shall see directly)

\footnotetext{
1 i.e. morphologically speaking.
} 
from the lateral bundles of one side of the petiole; in cach case, viz. of Paeonia and Calycanthaceae, the midrib-bundle passes into the stemcylinder, while the concentric and inversed collateral bundles respectively constitute a cortical system for a less or greater distance down the stem (Text-fig. 4).

Now it is interesting to note that in the majority of plants, when the transition from a cylinder to an arc of bundles takes place in the base of the petiole, it is the dorsal which may be said to dominate and absorb the ventral bundles with which they unite, leaving the dorsal arc as a result of the process. But in the Calycanthaceae precisely the reverse happens : for the ventral bundles dominate and absorb, so to speak, the dorsal, with the result that a ventral and, therefore, necessarily inverted, system of bundles is left over which persist right through the entire internode; the large size of each inverted bundle is due to the fact that it represents the fusion of two ventral bundles. It may be objected that no ventral bundles which unite with the dorsal actually exist in the leaf-base, as in other orders. This is true : but what I have suggested above represents what I believe has occurred in the phylogenetic sequence of events, the probable successive steps of which may be indicated as follows :-

(I) The ventral bundles of the petiole-cylinder pass across and fuse with the dorsal ones, a dorsal arc resulting;

(2) a half-way stage, represented to-day by Paeonia, Berberidopsis, \&c., in which both ventral and dorsal bundles are equally strong and both refuse, as it were, to effect a complete union;

(3) the dorsal bundles, with exception of the midrib, pass across and unite with the ventral, a ventral arc, complete only in its lateral portion, resulting ;

(4) the ventral bundles are pushed further and further downwards until they disappear from the leaf and occur only in the cortex of the stem, as in Calycanthaceae.

Hence, it appears to me to be not strictly, but rather only metaphorically, true to say that the inverted cortical bundles are leaf-traces in the sense that they emanate directly from the leaves. My own observations certainly show that, as regards the ontogenetic history, four lateral bundles from the petiole-arc pass into the cortex of the stem and unite with strands which are already in existence there as, in a sense, cauline strands. These latter are far too large in size to belong to the lateral bundles of the petiole. My conclusion is, that they belong in present actuality, though not phylogenetically nor essentially, to the stem and not to the leaf. Phylogenetically, they are leaf-traces. This is in agreement with the conclusions of Van Tieghem and Hérail ; the older authors like De Bary are, I am convinced, in error in regarding these bundles as leaf-traces. ${ }^{1}$

${ }^{1}$ Hérail says in effect that the inverted cortical bundles of Calycanthaceae are not derived from 
The facts of the ontogenetic apical development of the stem would probably be of no use to us in settling this question, for the cortical bundles would probably be seen in process of formation above the insertion of the bighest and youngest leaf, i.e. they ought to, from what we see in the mature structure; the fact that these strands have no connexion with the central cylinder and only an indirect connexion with the leaf shows them to be cauline.

During this sequence the dorsal midrib is early differentiated and remains unaffected by any subsequent events.

The persistence of the inverted orientation of these bundles may perhaps be due to two physiological causes: (I) the fact that these bundles bear no relation to the stem-cylinder; (2) the fact that a dense arc of sclerenchyma occupies the dorsal (outer side), the usual position for the bast-fibres, causing the factor of orientation to become an indifferent one.

Hence the structure of the leaf of Calycanthaceae is not so highly modified as would at first appear; the presence of a dorsal arc of bundles only is merely apparent: the ventral system exists as well, but has become transferred, as in Paeonia, into the cortex of the stem. ${ }^{1}$

Thus we see that the structure of the Calycanthaceous stem is not so peculiar and so isolated as has hitherto been supposed; in the preceding pages I have, it seems to me, fully accounted for its supposed vagary in possessing such peculiar structures as inverted cortical bundles. I have also accounted for and explained the meaning and origin, hitherto unattempted, of the concentric cortical strands of Magnoliaceae and Paeonia.?

Throughout these various orders we find the different phylogenetic stages stereotyped in the actual structure of present-day species. This is especially well seen in the Anonaceae. In Artabotiys, Polyalthia, and Uvaria we see a primitive structure extending through the greater part of the leaf, the base only showing the more modified, advanced structure; in Monodora, the structure which occurs only in the basal region of the leaf of Uvaria is here typical for the organ as a whole, indicating a greater advancement for the genus; the arc-shaped contour of the lateral bundles in this plant (Monodora) represent in the ontogeny a congenital fixation of

the lateral bundles of the leaf, but, on the contrary, they supply these bandles to the leaf; they possèss a cambium and a much larger amount of phloem than the lateral leaf-bundles; their whole structure is different and more voluminous. Van Tieghem says that these bundles 'sont donc, an même titre que la stêle, des éléments constitutifs de la tige, et c'est par erreur qu'on les a considértes jusqu'ici comme de simples méristèles foliaires.' I have arrived, quite independently of both these authors, at the same conclusion.

1 This fact need not seem strange when we remember that stem and leaf are so intimately conjoined and related as I hold, on the phyton theory, to be the case.

- The structure of the peduncle in all three groups represents the ancestral point of common agreement and union, for this organ has varied less in structure in the course of evolution than has the regetative stem; hence the structure of the latter will represent the diverging lines of disagreement and separation; bat we must not be misled thereby. 
that stage in the phylogeny in which a bundle from the ventral side is in the act of uniting with a bundle of the dorsal arc; in other orders, viz. Ranunculaceae and Magnoliaceae, we see this process actually taking place in the ontogeny; in Anonaceae and Paeoniaceae the process is no longer seen in actual operation, but certain stages of it have become fixed and arise congenitally as such in the individual life-history. Eupomatiz represents the most advanced type of this order in which an ordinary arc of bundles extends throughout the leaf. The concentric bundles which occur in the leaf of this order are homologous with those which occur in the cortex of the stem of Magnoliaceae and Paeonia which is only another instance of the fact that a given structure which in one group of plants is found only in the leaf, may in another occupy that part of the stem which is a direct continuation of the leaf ; this supports my view of the origin of the cortical bundles of Calycanthaceae and also the phyton theory.

In conclusion I must thank the authorities of the Royal Gardens, Kew, for valuable material supplied to me for this work.

\section{EXPLANATION OF FIGURES IN PLATES XXXII AND XXXIII}

Illustrating Mr. Worsdell's paper on the Vascular System in the Ranales.

Abbreviations nsed : $\rightarrow$ - $c b=$ ventral cortical bundle; $v b=$ ventral bundle ; $c x=$ cortex ; $\mu b b$ a medullary bundles; $c c$ a central cylinder of stem; $a x . c$ a cylinder of axillary branch; $a b=$ leaf-base; $c \delta=$ cortical bandle; st. $b=$ stipular bandles; $h p=$ hollow pith; $p=$ pith.

All figures are diagrammatic, and represent transverse sections.

Fig. I. Amemone rivularis, Buch.-Ham.; flowering stem. stem.

Fig. 2. Anemene nemorosa, L. ; segment of central cylinder, from bracteal node of flowering

Fig. 3. Anemone nemorosa, L.; typical region of petiole.

Fig. 4. Axemone apennina, L, typical region of petiole.

Fig. 5. Anemone sylvestris, L ; flowering stem.

Fig. 6. Helleborus viridis, L ; typical region of petiolc.

Fig. 7. Helleborus adorus, Waldst. and Kit. ; subdivision of lamina.

Fig. 8. Thalictrum fiavum, L ; typical region of petiole.

Figs. 9, 10, 11. Thalictrum flazum, L.; successive modifications in sheathing base of petiole in passing from above downwards.

Fig. I 2. Thalictrum ficoum, L; segment of flowering stem.

Fig. 13. Clemtatis Vitalba, L.; stem.

Fig. I4. Clematis heracleifolia, DC.; typical region of petiole.

Fig. 15. Clematis alpina, Mill; typical region of petiole.

Fig. 16. Caltha palustris, L. ; typical region of petiole.

Fig. 17. Callha palusiris, L.; lower region of petiole.

Fig. 18. Caltha palustris, L.; base of petiole after union with stem.

Fig. 19. Paconia, sp. (herbaceous type); typical region of petiole. 


\section{Worsdell. - A Study of the Vascular System in Ranales.}

Fig. 20. Paconia, sp (herbaceons type); base of petiole.

Figs. 2 I, 22. Paconia, sp. (herbaceous type); successive stages in union of leaf-base with stem.

Fig. 23. Pacorita, sp. (herbaceous type); peduncle.

Fig. 24. Calycanthus foridus, L.; typical region of petiole.

Fig. 25. Calycanthus floridus, L. ; stem.

Fig. 26. Calycanthus floridus, L.; pednncle.

Fig. 27. Manglietia insignis, Blume (Magnoliaceae) ; typical region of petiole.

Figs. 28, 29, 30. Manglictia insigris, Blnme; successive stages in union of petiolar vascular system with that of stem.

Fig. 3r. Illicium Cambodiarium, Hance; typical region of petiole.

Fig. 32. Illicium Cambodianum, Hance; anion of leaf-base with stem.

Fig. 33. Liriodendron tulipifera, L. ; pedoncle.

Figs. 34-37. Polyallkia suberosa, Benth. and Hook; successive stages from typical part of petiole (Fig. 34, monostele or cylinder) downwards tbrongh the intermediate 'polystelic' condition (Fig. 35, see Paconia) to the simple arc (Fig. $3^{6}$ ), and the union of the latter with the stemcylinder (Fig. 37 ).

Fig. 38. Uvaria stylanica, L. ; typical region of petiole.

Fig. 39. Uvaria Narum, A. D. C.; peduncle.

Fig. 40. Cananga odorala, Hook. f.; petiole.

Fig. 41. Podophyllum peltatum, L.; flowering stem.

Fig. 42. Epimedium pinnatum, Fisch.; typical region of peliole.

Fig. 43. Nardina domestica, Thunb. ; segment of petiole.

Fig. 44. Nandina domestica, Thunb.; segment of stem.

Fig. 45. Berberidopsis corallina, Hook f,; typical region of petiole.

Fig. 46. Berberidopsis corallina, Hook $\mathrm{f}$; l lower region of petiole.

Fig. 47. Berberidopsis corallina, Hook f.; nnion of leaf-bundles with stem-cylinder.

Fig. 48. Hydrastis canadersis, L. ; flowering stem.

Figs. 49-52. Berberis Aquifolitum, Pursh.; successive stages in pasage from typical part of petiole (Fig - 49) to anion of leaf-base with stem (Fig. 52). 

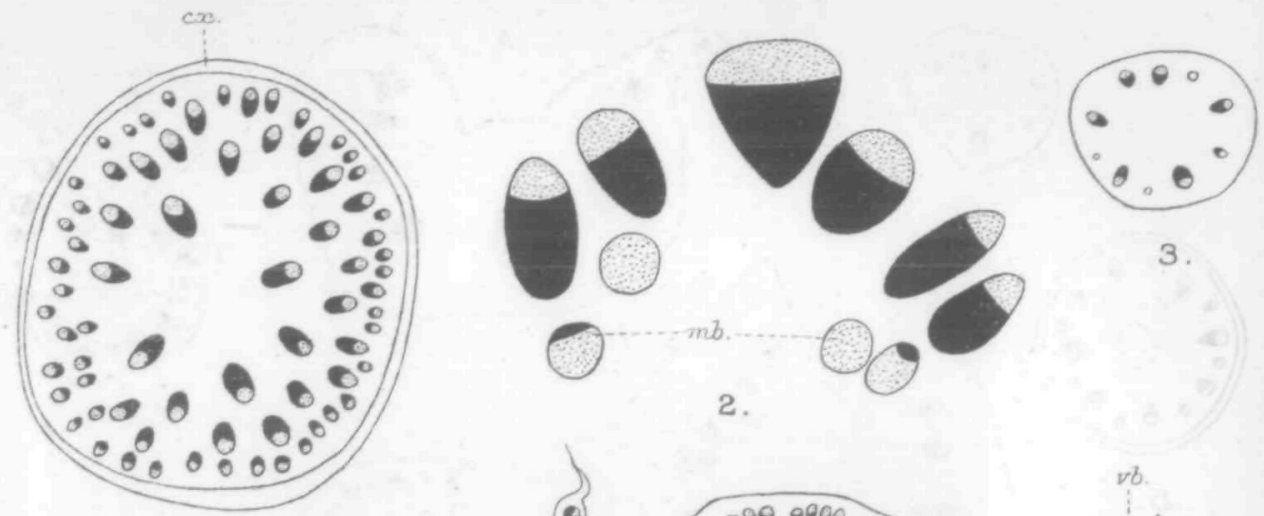

2.
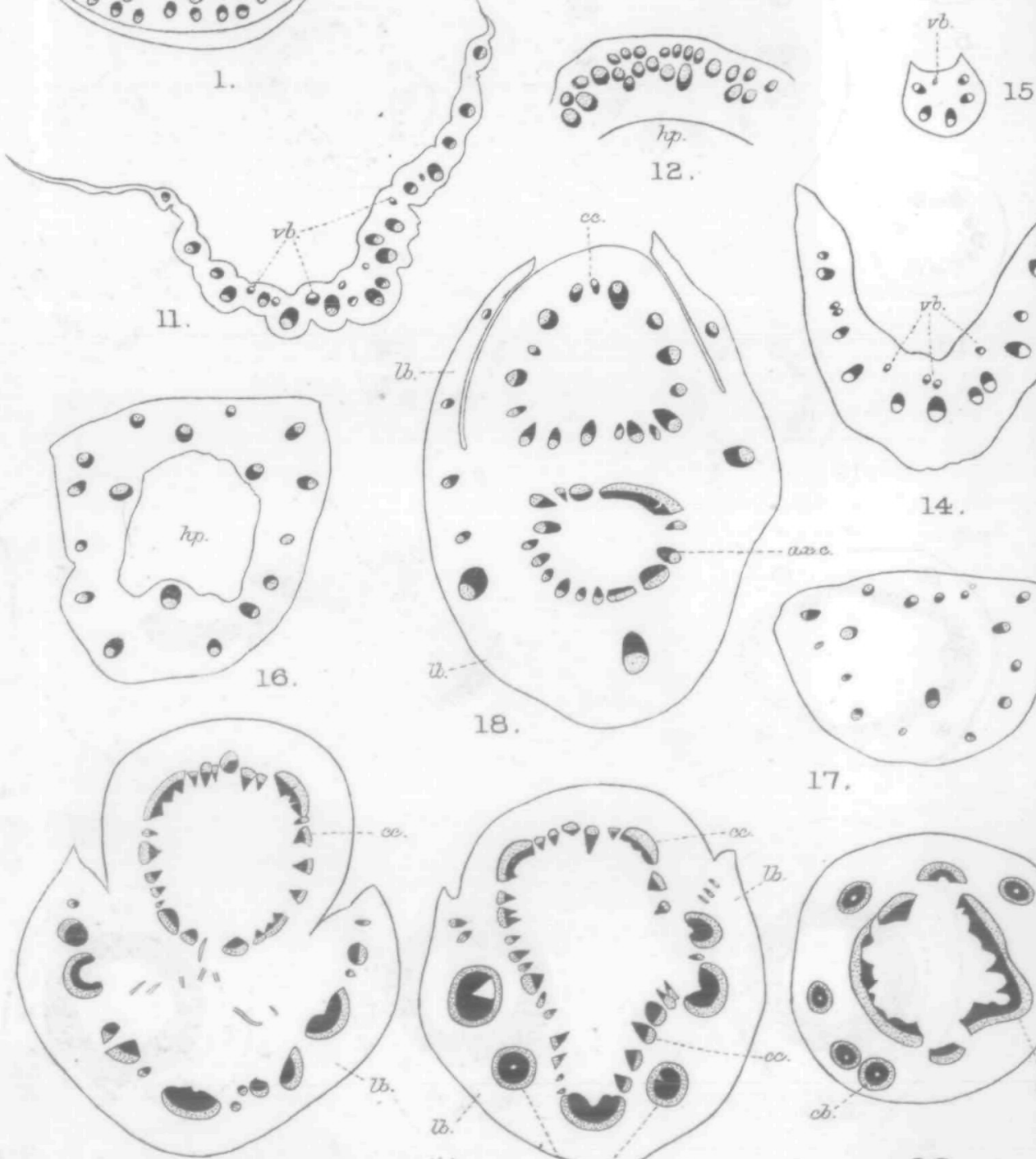

21.

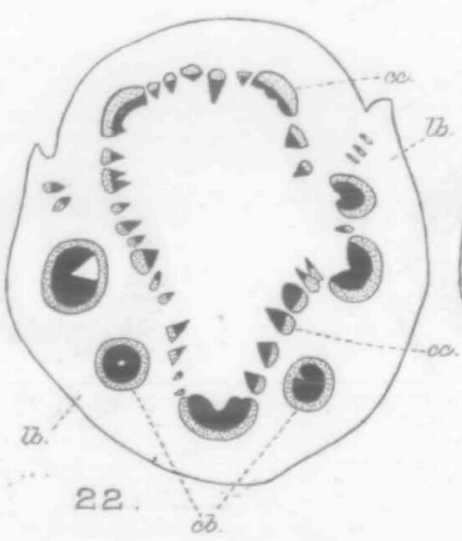

17.

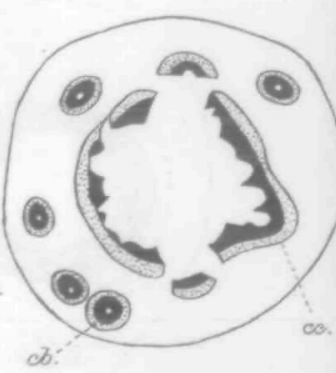

23. 

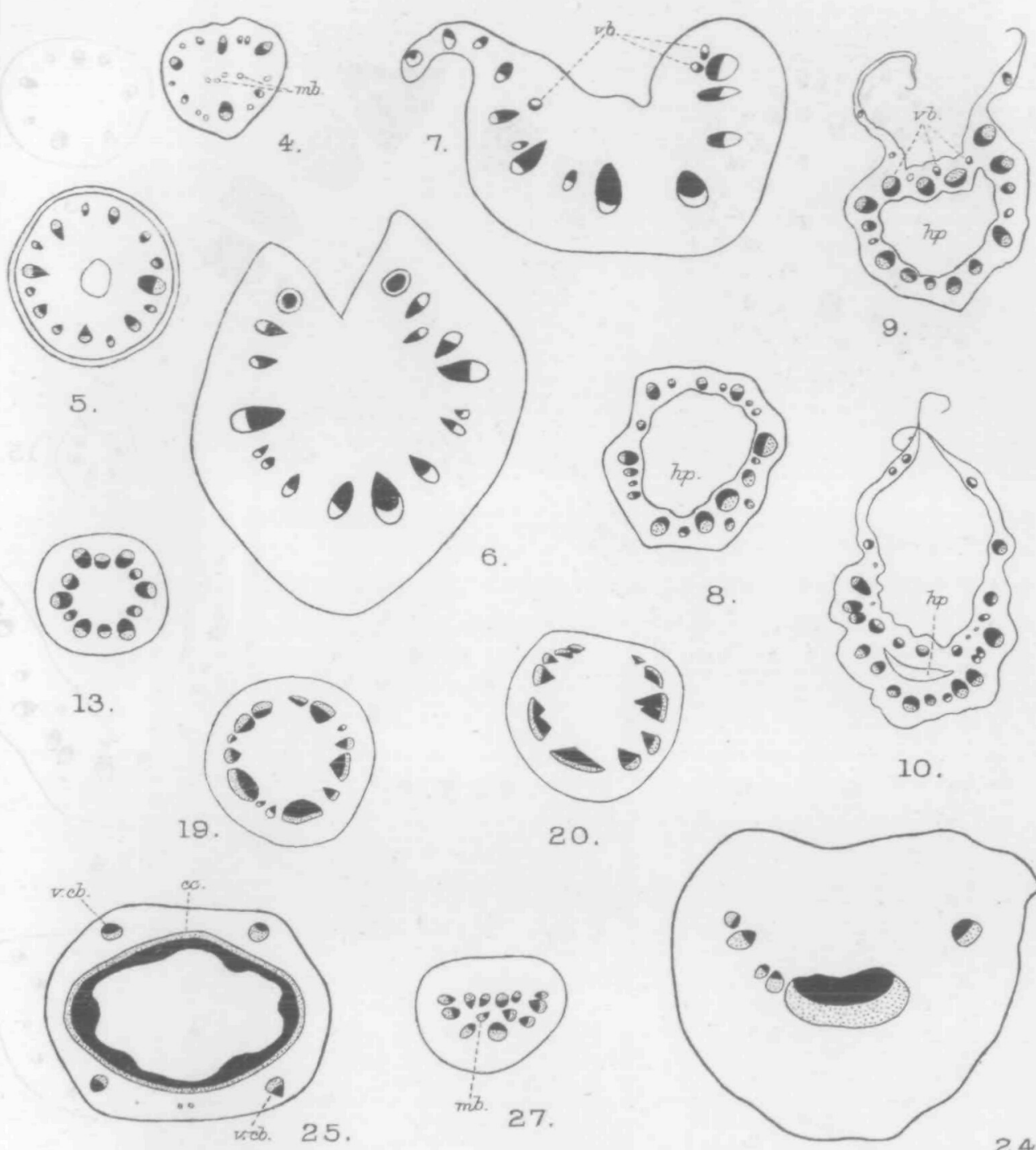

9.

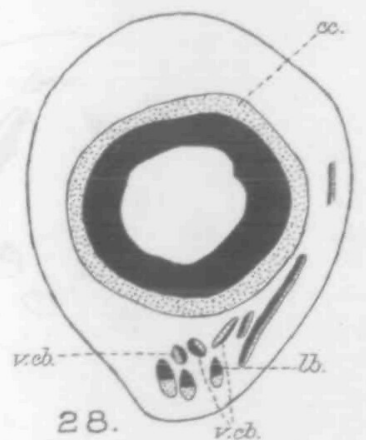

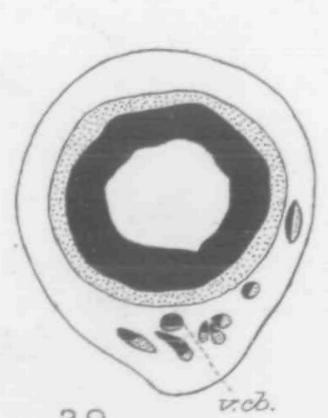

29.

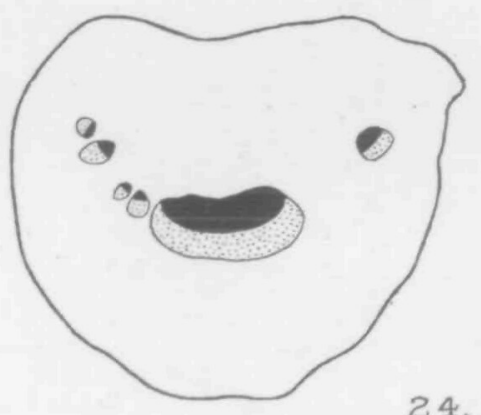

24.

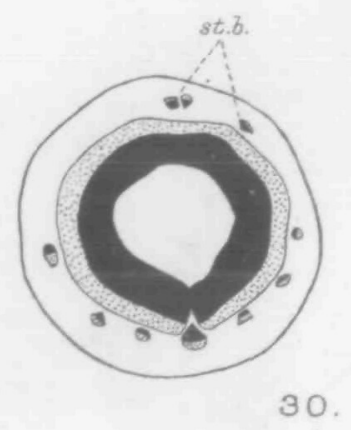

Huth, lith. et imp.

\section{CULAR SYSTEM.}


by University of California, Santa Barbara user
on 09 March 2018 


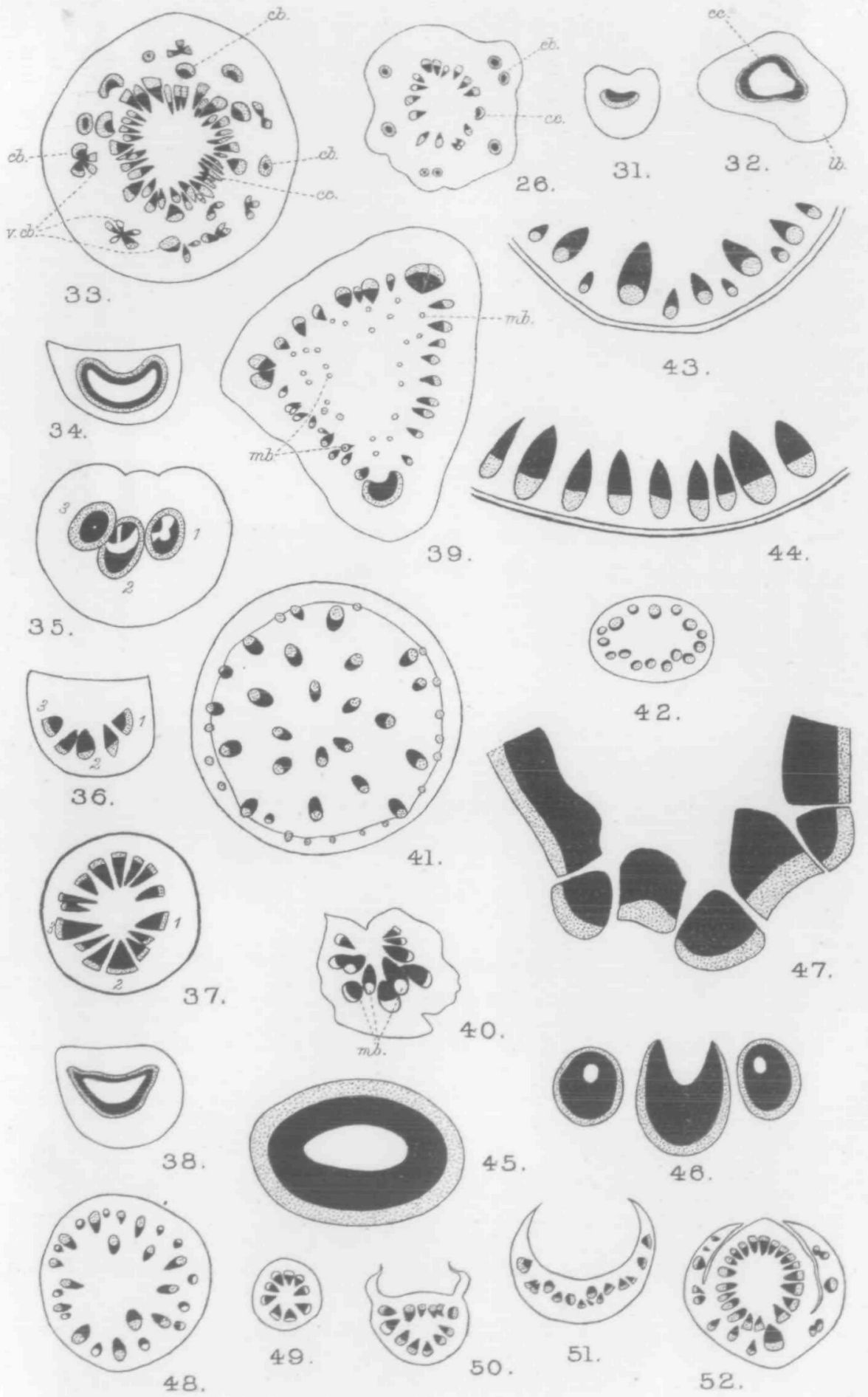

Huth, lith, et imp. 
